\title{
Editorial
}

\section{Stroke: A Neglected Epidemic in India}

Stroke is a cause of significant morbidity and mortality. It is the second cause of mortality globally and leading cause of disability. ${ }^{[1]}$ The prevalence of stroke in India in an elegant community-based study is $545.10 \%$ (95\% confidence interval [CI], 479.86-617.05) per 100,000 persons. The case fatality rate is found to be $41.08 \%$ (95\% CI, 30.66-53.80), occurring within 30 days. ${ }^{[2]}$

The community-based epidemiological studies are helpful in understanding the magnitude of burden due to stroke in a defined population, delineating risk factors, better insight of disease pathogenesis, standard of care, and population-based strategies to reduce the incidence of stroke. ${ }^{[3]}$

The burden of stroke has been decreased in developed nations due to better control of risk factors, creating awareness and symptoms of stroke at community level, well-organized acute stroke care settings and rehabilitative centers. ${ }^{[4]}$

India is facing problem of both communicable and non-communicable diseases. Certain risk factors such as hypertension, diabetes, tobacco consumption, dyslipidemia, sedentary lifestyle, obesity, rheumatic heart disease, and dietic factors are widely prevalent in India. In the near future, India will face pandemic of diabetes. ${ }^{[5]}$

Due to changing demographics and increased longevity, the burden of stroke is increasing in our population. ${ }^{[2]}$

The nihilistic attitude about treating strokes has waned away with the availability of advanced neuroimaging techniques and better therapeutic options. The landmark National Institute of Neurological Disorders and Stroke trial related to thrombolytic therapy has revolutionized the treatment of acute ischemic stroke. Since then, many trials have established the efficacy of recombinant tissue plasminogen activator (rtPA). ${ }^{[6]}$

Unfortunately, only $6 \%$ of appropriate patients of acute ischemic stroke received thrombolytic therapy throughout the world. The endovascular therapy of stroke has made strong imprints in acute stroke treatment based on sufficient evidence. Both types of therapy, chemical and mechanical thrombolysis, are based on principles of recanalization and reperfusion. ${ }^{[7]}$

The barriers for acute thrombolytic therapy in India are late arrival of patient after window period due to traffic congestion, prehospital ambulance services, lack of computed tomography scan facilities in wide geographical areas, availability of neurocritical care, and less number of trained personnel. The various state governments have implemented National Noncommunicable Disease Programme, and stroke prevention and control is one of them. The government is supplying rtPA in various district hospitals free of cost. ${ }^{[8]}$

The anticoagulants are drug of choice in cardioembolic stroke, cortical venous thrombosis, and stroke occurring due to arterial dissection. Apart from old time-tested vitamin $\mathrm{K}$ antagonist warfarin, novel anticoagulants rivaroxaban, apixaban, and dabigatran are approved and evidence-based efficacious drugs with almost no need of monitoring and fewer side effects. ${ }^{[9]}$

The hemorrhagic stroke is more lethal, and case fatality rates are from $33 \%$ to $45 \%$. The specific therapies available are hemostatic agents (factor VII a), surgical evacuation, and control of blood pressure. Unfortunately, hemostatic agents have not proved its efficacy in randomized controlled trials. The surgical evacuation in hemorrhagic stroke related surgical trial in lobar intracerebral hemorrhage (STICH1 and STICH2) has not shown promising evidence, except in subset of patients with superficial and small-sized hemorrhages. In cerebellar hematoma, there is substantial evidence in favor of surgical evacuation. ${ }^{[10]}$

Del Brutto et al. conducted a population-based prospective study and tried to find out mortality related to nonfatal stroke and all-cause mortality among older rural population in Ecuador. They concluded with the observations that nonfatal stroke and increasing age increased the risk of overall mortality in their rural population. The body mass index had inverse relation with mortality (obesity paradox). ${ }^{[11]}$

Finally, the population-based studies related to stroke are desperately required in India, so as to have effective population-based strategies, especially control of risk factors, which will help to reduce the incidence of stroke and stroke-related mortality.

Rajesh Verma

Department of Neurology, King George's Medical University, Lucknow, Uttar Pradesh, India

Address for correspondence: Dr. Rajesh Verma, Department of Neurology, King George's Medical University, Lucknow - 226 003, Uttar Pradesh, India. E-mail: drrajeshverma32@yahoo.com

\section{REFERENCES}

1. Lozano R, Naghavi M, Foreman K, Lim S, Shibuya K, Aboyans V, et al. Global and regional mortality from 235 causes of death for 20 age groups in 1990 and 2010: A systematic 
analysis for the Global Burden of Disease Study 2010. Lancet 2012;380:2095-128

2. Das SK, Banerjee TK, Biswas A, Roy T, Raut DK, Mukherjee CS, et al. A prospective community-based study of stroke in Kolkata, India. Stroke 2007;38:906-10.

3. Ovbiagele B, Nguyen-Huynh MN. Stroke epidemiology: Advancing our understanding of disease mechanism and therapy. Neurotherapeutics 2011;8:319-29.

4. Ovbiagele B. National sex-specific trends in hospital-based stroke rates. J Stroke Cerebrovasc Dis 2011;20:537-40.

5. Kulshrestha M, Vidyanand. An analysis of the risk factors and the outcomes of cerebrovascular diseases in Northern India. J Clin Diagn Res 2013;7:127-31.

6. National Institute of Neurological Disorders and Stroke rt-PA Stroke Study Group. Tissue plasminogen activator for acute ischemic stroke. N Engl J Med 1995;333:1581-7.

7. Hacke W, Kaste M, Bluhmki E, Brozman M, Dávalos A, Guidetti D, et al. Thrombolysis with alteplase 3 to 4.5 hours after acute ischemic stroke. N Engl J Med 2008;359:1317-29.

8. Badachi S, Mathew T, Prabhu A, Nadig R, Sarma GR. Hurdles in stroke thrombolysis: Experience from 100 consecutive ischemic stroke patients. Ann Indian Acad Neurol 2015;18:415-8.

9. Verma R. Role of anticoagulation in neurological practice. Indian J Med Res 2016;143:392-4.
10. Mendelow AD, Gregson BA, Mitchell PM, Murray GD, Rowan EN, Gholkar AR, et al. Surgical trial in lobar intracerebral haemorrhage (STICH II) protocol. Trials 2011;12:124.

11. Del Brutto OH, Meral RM, Victor J. Del Brutt O. Nonfatal stroke and all-cause mortality among community-dwelling older adults living in rural ecuador: A population-based, prospective study 2018;9:551-5.

This is an open access journal, and articles are distributed under the terms of the Creative Commons Attribution-NonCommercial-ShareAlike 4.0 License, which allows others to remix, tweak, and build upon the work non-commercially, as long as appropriate credit is given and the new creations are licensed under the identical terms.

\begin{tabular}{|l|l|}
\hline \multicolumn{2}{|c|}{ Access this article online } \\
\hline Quick Response Code: & $\begin{array}{l}\text { Website: } \\
\text { www.ruralneuropractice.com }\end{array}$ \\
& \\
& \\
\hline
\end{tabular}

How to cite this article: Verma R. Stroke: A neglected epidemic in India. J Neurosci Rural Pract 2018;9:453-4. 